\title{
Conflicts Management Model in School: A Mixed Design Study
}

\author{
Soner Doğan ${ }^{1}$ \\ ${ }^{1}$ Education Faculty, Cumhuriyet University, Sivas, Turkey \\ Correspondence: Soner Doğan, Education Faculty, Cumhuriyet University, Sivas, Turkey. Tel: 90-3462-19-1010. \\ E-mail: snr312@gmail.com
}

Received: January 18, 2016

Accepted: March 8, $2016 \quad$ Online Published: March 22, 2016

doi:10.5539/jel.v5n2p200

URL: http://dx.doi.org/10.5539/jel.v5n2p200

\begin{abstract}
The object of this study is to evaluate the reasons for conflicts occurring in school according to perceptions and views of teachers and resolution strategies used for conflicts and to build a model based on the results obtained. In the research, explanatory design including quantitative and qualitative methods has been used. The quantitative part of the research has been designed as the relational quantitative model. Data have been collected from 216 teachers working in the province of Sivas through the Scale of Reasons for Conflicts and the Scale of Resolution Strategies. The qualitative part of the research has been conducted in conformity with the case study design. Data has been gathered from 20 teachers working in the province of Sivas through open-ended questions. According to the research findings, the reasons for conflicts occurring in school has been diversified based on the way of doing things, individual differences and school management. The strategies for conflict solution used by the teachers vary according to school shareholders in which they experience conflict. Furthermore, findings have been obtained regarding that there is not any common management policy in the school. In this context, "Management Model for Conflict in School" for building conflict management culture in the school has been made.
\end{abstract}

Keywords: conflict, conflict management, conflict resolution strategies, teachers, mixed design

\section{Introduction}

The origin of conflict concept is equivalent to the history of humanity. The occurrence of conflicts in every environment in which human is present appears to us as normal. The subject of the conflict, especially starting from 1970's has been the center of attraction of organizational life particularly in the USA and the world. Even, one of the results that makes people sad and the other one that causes workforce losses and time loss of the organizations has led to countries to establish organizations and has led the organizations to attend actively to training in order to minimize these problems (Dağlı \& Sığrı, 2014).

When the word of conflict is heard for the first time, it comes to mind the concepts such as furiousness, fear, tension, anger, disappointment, distrust, hostility, damage, destruction, discussion. This fact shows that the idea of conflict or discussion evokes negative thoughts. Despite this fact, people perceive from conflict positive things such as an opportunity for personal development, intellectual revolt, excitement, encouragement (Stulberg, 1987; Tjosvold, 1991; Seval, 2006). On the other hand, conflict is part of the daily life and it is inevitable. Conflict will continue as long as there are differences in values, beliefs, cultures of people and groups. In this regard, conflict can be defined as divergence naturally occurring in the life (Sarpkaya, 2002; Karip, 2003; Stepsis, 2003; Fritz, Brown, Lunde, \& Banset, 1999; Walton, 1987; O’Toole, 1999; Steed, 1985; Laursen \& Hafen, 2010; Lıpsky, Seeber, \& Fincten, 2003; Özmen \& Aküzüm, 2010; Öztaş \& Akın, 2009).

Conflict is an important part of thinking, watching, performing and managing in an organization (Tjosvold, 1991). In this context, it has been known that conflict is an organizational reality and in there are the people who lead up to the conflict and have different characters, understandings, value judgment, world-view, objectives, attitudes, beliefs, personalities, roles communication skills and interests every organization (Atay, 2001; Parker \& Stone, 2003; Seval, 2006; Demir, 2010; Ceylan, Ergün, \& Alpkan, 2011). These conflicts and divergences cause various conflicts in the social and organizational life (Akgün, Yıldız, \& Çelik, 2009; Zia \& Syed, 2013; Quinn, Faerman, Thompson, \& Mcgrath, 2003; Y1ldızoğlu \& Burgaz, 2014). These conflicts increase much when the works intersect, become complex and ambiguous and it is supposed to work for long hours (Sayles, 1993; O'Toole, 1999). Thus, conflict is one the most important and the most urgent subjects that are required to 
be discussed (Sharma, 2014). However, it has been seen that the individuals try to manage in the direction of certain behavior models in the conflicts experienced (Toytok \& Açıgöz, 2013).

Conflict management is an old fact as common life (Tjosvold, 1991) and in our day it plays a crucial role in terms of forming a good work environment (Mayer, 1990; Sharma, 2014). In an effective conflict management, it is required to identify properly the source of conflict (Sökmen \& Yazıcıoğlu, 2005) and to analyze the reasons for it correctly (Ceylan, Ergün, \& Alpkan, 2011). Therefore, it may harm organization's structure if it is not managed well in the short and long term. If the conflict is managed correctly, it provides benefits in the long term to all the related parts and organization (Zia \& Syed, 2013; Seval, 2006; Karip, 2003; Özmen \& Aküzüm, 2010). For this reason, it is necessary to manage the conflicts and divergences constructively, positively and in the manner that it integrates the conflicting parties and enhances the relations as far as possible (Türnüklü, 2005). Thus, people get encouraged concerning the development of values, behaviors, knowledge and civil standards (Johnson \& Johnson, 1996). Along with the comprehension of the contributions of conflict management to organizational life, perceptions for management concept has significantly got changed recently. Conflict perception has changed towards listening to others, negotiate with the others, comprehension of cultural differences and skill of value adding instead of exercising power over and struggle with them (Prause \& Mujtaba, 2015).

When strategies of conflict resolution are mentioned, it comes to mind firstly the classification which was made by Rahim (1983) through benefiting from (1976) Conflict Management Model of Ruble and Thomas (1976). In this classification, the strategies of the conflict solution are divided into five strategies including integration, reconciliation, compromise, avoidance and domination. These can be defined as: The integration is worrying both about himself/herself and both the other party and making efforts to solve the problem in case of conflict; reconciliation is reaching a decision which is seen as reasonable by the conflicting parties through making sacrifices from their objectives; compromise is that one of the conflicting parts gives up some of his/her claims in order to satisfy the other party's claims and expectations, Domination is ignoring the other party's feelings, opinions and expectations and trying to reach his/her objective. According to Conerly and Tripathi (2004), no one can manage conflicts in the same way. Every conflict style has strong and weak parts and individuals can use all styles in any level. In order to adapt to different situations, it is necessary to use different strategies. In a conflict, individuals may feel strong for the realization of the objectives. However, in another conflict they may maintain the relations and cooperation in accordance with the objectives.

The scholar organizations of which fundamental input is human and in which human interaction is experienced intensely are living organisms. One of the most important factor providing development of the schools is conflict (Tjosvold, 1997; Nural, Ada, \& Çolak, 2012; Yıldızoğlu \& Burgaz, 2014; Özmen, Aküzüm, \& Aküzüm, 2011). The conflict is an important fact that is required to describe in conformity with the skill of adaptation to economic, political and social changes arising from the environment in the schools providing general education (Voronin, 1995). Both the objectives of the schools and the unique conditions stemming from the quality and quantity of human dimension (educators, students, families) lead to organizational studies. In other words, the occurrence of conflicts frequently in schools is a normal case (İnand1, Tunç, \& Gündüz, 2013; Miller \& Leyden, 1999). Nowadays, conflicts experienced in schools have become more complex depending on the needs of the new generation (Vasilescu, Popescu, \& Popescu, 2012). In fact, conflicts experienced in schools along with ethnical origin, socio-economic status, gender roles, technological developments may arise from the increase of tendency to violence among the students (LaCour \& Tissington, 2011). Cohen (2005) examines the conflicts experienced in schools in 4 steps. In the first step, conflict prevention, in the second step conflict management, in the third step with the support of the third party and in the fourth step the suspension includes cessation of destructive conflicts through arbitration.

When the literature examined, it is seen that it was expected from school management to resolve conflicts experienced in school. In this context, it is expected from school managers Arslantaş and Özkan (2012) to be sensitive to concerns and needs of the teachers and other workers in the school; Kırçan and Bostanc1 (2012) to see every conflict as a opportunity if necessary, and to select and practice the most convenient strategy for conflict management according to the problem experienced and to implement the results in accordance with the school's objectives; Yıldızoğlu and Burgaz (2014) to have information about the workers' personality characters; Açıkalın (1998) to establish a system for information (getting information) which operates well in the school; Özgan (2011) to gain trust of the teachers. However, it is not true to see the conflict management as if the responsibility only belongs to the school management. Such a comprehension that the conflicts experienced in the schools cannot be resolved without the intervention of the school management and this comprehension will also passives the other school shareholders concerning this subject. In this regard, it is necessary that all school 
shareholders contribute to the process of conflict resolution. As Jones (2004) stated that the intervention of the school shareholders with constructive and cooperative comprehension will make the school environment safer and more proper. Stepsis (2003) as it is same in human skills, the fact of being teachable of conflict resolution is the sign that all school shareholders can help to the solution of the conflicts experienced in school.

When the studies which have been conducted regarding conflict management in education institutions are examined, it has been seen that these studies (Özmen \& Aküzüm, 2010; Yürür, 2009; Iordanides \& Mitsara, 2014; Arslantaş \& Özkan, 2012; Kırçan \& Bostanc1, 2012; Toytok \& Açıkgöz, 2013; Türnüklü, 2005; Akgün, Yıldız, \& Çelik, 2009; Karakuş \& Çankaya, 2009; Yıldızoğlu \& Burgaz, 2014; İnandı, Tunç, \& Gündüz, 2013; Serin, Balkan, \& Soran, 2014; Shabbir, Atta, \& Adil, 2014; Konak \& Erdem, 2015) generally focus on the strategies of conflict solution used by school management. Yet, teachers also may have experience conflict with the other school shareholders concerning individual differences, the way of doing things, the attitude of the school management. However, the studies conducted regarding the conflict strategies teachers used are in limited availability (Güllüoğlu, 2013; Dağlı \& Sığrı, 2014). In this research, depending on teachers' perception and views, the reasons for conflict experienced in the school and the strategies of conflict resolution strategy they used have been examined. In addition, any study conducted with mixed method concerning conflict management in education institutions in literature has not been observed. In this context, this study is different from other studies and contributes to literature.

\section{Methodology}

The research has been constructed according to a mixed method. If the researcher has an opportunity to reach qualitative and quantitative data, it is the most ideal approach (Creswell, 2013). In this regard, explanatory design in which quantitative data and then qualitative data are firstly gathered has been used (Fraenkel \& Wallen, 2006). The object of using both research methods together aims get more comprehensive and detailed information and to make reliable and correct assumptions.

The qualitative part of the research is one of the descriptive studies based on relational screening model that is general screening models. According to Karasar (2011) relational screening model is a research model that aims to determine the covariance and grade among two or more variables. In this regard, the reasons for conflicts experienced in school and conflict resolution methods used according to variables such as gender, the state of education and age have been examined.

Case design has been used in the qualitative part of the research. The aim of the qualitative case study is to present the results concerning certain cases. The basic characteristic of the study is to analyze the some cases through participants' observations and interviews or through gathering documents (Yıldırım \& Şimşek, 2011). In this context, the reasons for conflicts experienced in school and the strategies conflict resolution used has been examined with the open-ended questions

\subsection{Study Group}

In the quantitative part of the research, the study group includes 216 teachers who are selected randomly and work in 22 secondary schools in the city center of Sivas. Demographic information concerning teachers who participated in the research has been presented in Table 1.

Table 1. Demographic information concerning teachers (quantitative part)

\begin{tabular}{llll}
\hline Variables & & Frequency (f) & Percentage (\%) \\
\hline \multirow{2}{*}{ Gender } & Female & 114 & 52.8 \\
& Male & 102 & 47.2 \\
\hline \multirow{2}{*}{ The State of Education } & Under Graduate & 175 & 81.1 \\
& Post Graduate & 41 & 18.9 \\
\hline \multirow{2}{*}{ Age } & Between 21-30 & 69 & 31.9 \\
& Between 31-40 & 101 & 46.7 \\
& Between 41 and over & 46 & 21.4 \\
\hline
\end{tabular}


In the qualitative part of the research, while determining the participants, the maximum variation sampling method among the purposive sampling methods has been used. Maximum variation sampling method reflects the highest level diversity of individuals that can be part of the problem studied in this sampling with forming a small sampling (Yıldırım \& Şimşek, 2011). In this regard while the participants were determining who is selected as sample, the parameters of gender, state of education and age have been taken into consideration. Demographic information concerning the participant teachers has been presented in Table 2 in detail.

Table 2. Demographic information concerning the teachers (qualitative part)

\begin{tabular}{llll}
\hline Nickname & Gender & Age & State of Education \\
\hline P1 & Female & 27 & Under Graduate \\
P2 & Female & 41 & Under Graduate \\
P3 & Male & 36 & Post Graduate \\
P4 & Male & 51 & Post Graduate \\
P5 & Male & 42 & Under Graduate \\
P6 & Male & 31 & Under Graduate \\
P7 & Female & 28 & Post Graduate \\
P8 & Male & 29 & Under Graduate \\
P9 & Female & 36 & Under Graduate \\
P10 & Male & 27 & Under Graduate \\
P11 & Female & 25 & Post Graduate \\
P12 & Female & 26 & Post Graduate \\
P13 & Female & 25 & Post Graduate \\
P14 & Female & 35 & Post Graduate \\
P15 & Male & 31 & Post Graduate \\
P16 & Female & 42 & Under Graduate \\
P17 & Male & 34 & Under Graduate \\
P18 & Female & 44 & Post Graduate \\
P19 & Male & 34 & Under Graduate \\
P20 & Male & 48 & Under Graduate \\
\hline & & & \\
\hline
\end{tabular}

\subsection{Tools for Collecting Data}

The Assessment instrument used in the quantitative part includes three parts: The Scale of Reasons for Conflict (Uysal, 2004) and The Scale of the Conflict Resolution Strategies (Gümüşeli, 1994).

The Scale of Reasons for Conflict was adapted by Uysal (2004) from the study in the banking sector conducted by Canl (2001). The scale includes 28 expressions and has been prepared according to the five-Likert-type scale system. The scale includes three dimensions such as the way of doing things, individual differences and management. Within the scope of this research, a factor analysis with 183 teachers' participation has been conducted on the scale. 3 articles that have factor load value lower than 30 have been removed from the scale. As a result of the analysis, 3 dimensions have been obtained, and the dimensions have been named as the same as in the origin of the scale. It has been observed that factor load values of the articles vary from 41 to 82 . Cronbach Alpha reliability coefficient of the scale in the dimension of the way of doing things has been calculated as 85 , personal differences 82 , management 91 and totally 88 . According to these results, the Scale of the Reasons for Conflict is a scale that has validity and reliability. In the scale there are articles such as "my co-workers work less than me, we cannot agree upon work distribution, the directors grant privilege to some of my co-workers".

The Scale of Organizational Conflict developed by Rahim (1993) was adapted to Turkish by Gümüşeli (1994). The Scale of Organizational Conflict includes 28 expressions, and it has been prepared according to the 5-Likert 
-type scale system. The scale has 5 dimensions such as integration, compromise, domination, avoidance and reconciliation strategies. Within the scope of this research, a factor analysis -with 183 teachers' participation- has been conducted on the scale. 2 articles that have factor load value lower than 30 have been removed from the scale. As a result of the analysis, 5 dimensions has been obtained and the dimensions have been named as the same as in the origin of the scale. It has been observed that factor load values of the articles vary from 43 to 78 . Cronbach Alpha Reliability Coefficient of the in the dimension of integration scale has been calculated as 91, compromise 83, domination 80, reconciliation 87 and avoidance 90 and totally 95 . According to these results, The Scale of Organizational Conflict is a scale that has validity and reliability. In the scale, there are articles such as: "I try to understand the problem with the other party correctly, I consent the other party's wishes, I suggest a mutual compromise to arrive at an agreement".

The qualitative data of the research has been collected through semi-structured interview form. In the process of development of gathering qualitative data, firstly open-ended questions that will be addressed to the participants has been addressed to two teachers who do not take place in the research's working group, it has been shown that the questions are clear and comprehensible according to the results obtained. Furthermore, the questions were subjected to the examination by academic members who are competent of qualitative studies and required corrections have been made. The questions addressed to the participant in the research as following:

1-What are the reasons for conflicts experienced in schools depending on the way of doing things? Explain.

2-What are the reasons for conflicts experienced in school depending on school management? Explain.

3-What are the reasons for conflicts experienced in schools depending on individual differences? Explain.

4-With whom do you experience conflict mostly in schools?

In this step, the information concerning the strategies of conflict resolution forming the dimensions of scale of Rahim (1983) such as reconciliation, integration, compromise, domination and avoidance has been given.

5-Which conflict strategies do you use while resolving the conflicts experienced with school management?

a-Why do you use these conflict strategies?

6-Which conflict strategies do you use while resolving the conflicts experienced with teachers?

a-Why do you use these conflict strategies?

7-Which conflict strategies do you use while resolving the conflicts experienced with students?

a-Why do you use these conflict strategies?

8-Which conflict strategies do you use while resolving the conflicts experienced with parents?

a-Why do you use these conflict strategies?

\subsection{Analysis of the Data}

In the qualitative part of the research, while analyzing subproblems of the research, t-test for paired comparison and one-way analysis of variance (ANOVA) for the multidimensional comparisons were used by benefiting from the SPSS.18 program. In the table formed according to the general distribution includes arithmetic average and the number of the participants.

In the qualitative part, face-to-face meetings were held which lasts totally 400 minutes with 20 teachers participated in the research voluntarily. The data recorded on the voice recorder was then transferred to the computer environment. In this regard, content and descriptive analysis methods were used. The aim of the content analysis of Cohen, Manion and Morrison (2007), is to edit, to classify, to compare the data and to draw conclusions from the data; whereas the aim of the descriptive analysis of Altunışı, Coşkun, Yıldırım and Bayraktaroğlu (2001) is to quote directly in order to reflect the views of individuals dramatically. For this purpose, the data has been analyzed in four steps such as data coding, finding the themes, editing the codes and themes, identification explication of findings. The same process has been followed by two participant and codes, categories and themes revealed in accordance with the common views of two participants. These codes, categories and themes were edited and the findings obtained has been identified and explicated. Furthermore, citations have been involved in the descriptive analysis frequently in order to reflect the views of the individuals dramatically. Nicknames like (P1, P2, P3, ... P20) was given to participants.

In the qualitative research, the reliability of the descriptive and the content depends on particularly the coding process. One of the most important characteristics of the categories that required bearing is that it should so clear that the same document used for the same purpose by another researcher can reach almost same results 
(Tavşancil \& Aslan, 2001). All data obtained during research process has been evaluated, separated coded by another researcher- except the researcher himself- and reached to the agreement. In the research, for the reliability calculation of whole codes was used the reliability formula Reliability=Agreement/(Agreement + Disagreement)] put forward by Miles and Huberman'n (1994). In each reliability calculation for each question, the results between $83 \%$ and $89 \%$ have been obtained.

\section{Findings}

In this part, quantitative and qualitative findings will be presented under a different title. As it has been described in the research method, the questions addressed to the teachers in the qualitative part have been structured such that they describe and support the findings.

\subsection{Quantitative Findings}

In the quantitative part of the research, teachers' perceptions regarding the reasons for conflicts experienced in school and their conflict resolution strategies will be firstly presented. Next the findings regarding gender, state of education and age variables will be presented.

According to the perception of the teachers, the way of doing things is at first rank among the reasons for conflicts in school. Individual differences and management dimensions succeed it respectively. When the data obtained concerning resolution strategies are examined, it is seen that the most common resolution strategy used by teachers is reconciliation Integration, avoidance; and compromise and domination succeed this respectively. It is striking that the avoidance precedes reconciliation strategy in the ranking. In the qualitative part concerning this result, more detailed analyzes have been carried out. The perception of teachers regarding the reasons for conflict and resolution strategies used has been presented in Table 3 .

Table 3. The general distribution of teachers' perception regarding the reasons for conflict and conflict resolution strategies used

\begin{tabular}{llll}
\hline & $\mathbf{n}$ & $\bar{x}$ & ss \\
\hline The reason for conflict (Total) & 216 & 3,55 &, 48 \\
The way of doing things & 216 & 3,96 &, 54 \\
Individual differences & 216 & 3,81 &, 45 \\
Management & 216 & 3,30 &, 74 \\
Conflict resolution strategies (Total) & 216 & 2,95 &, 62 \\
Integration & 216 & 3,04 &, 91 \\
Reconciliation & 216 & 3,68 &, 78 \\
Compromise & 216 & 2,52 &, 86 \\
Avoidance & 216 & 2,85 &, 74 \\
Domination & 216 & 2,35 &, 80 \\
\hline
\end{tabular}

When the research findings are examined according to variables of gender, the state of education and age, it has not been realized that there is any significant difference between teachers' perception of each three variable. The fact that the teachers have similar perceptions shows that all teachers are affected by conflicts experienced in the school environment. Since there are no significant differences, variables as mentioned earlier hasn't been mentioned in this research.

\subsection{Qualitative Findings}

In accordance with the views of the participants, the qualitative findings of the research have been collected under 9 themes. The theme titles are 1) Teachers' views regarding conflicts stemming from the way of doing things, 2) Teacher views regarding conflicts stemming from the individual differences, 3) Teacher views regarding conflicts stemming from school management, 4) Teacher views regarding conflicts experienced with school shareholders, 5) Teacher views regarding conflicts experienced between teachers and students, 6) Teacher 
views regarding conflicts experienced between teachers and managements, 7) Teacher views regarding conflicts between teachers and students, 8) Teacher views regarding conflicts experienced between teacher and parents.

\subsubsection{Teachers' Views Regarding Conflicts Stemming from the Way of Doing Things}

According to the views of the participants, using classrooms ranks first among the reasons for conflicts stemming from the ways of doing things in school. Respectively, not coming to class on time, the duty of watching, the differences between teaching lessons, social activities and school discipline succeeds it. Participants stated that classrooms are used in a day by different teachers, the classroom order are changed every time the teachers come there, the classrooms got dirty, even the board is not cleaned up. In this regard, Participant P3 stated that: "The classroom where we do our job. Thus, it has to be always proper and clean. However, some irresponsible teachers are using the classrooms as if it only belonged to him. Therefore, we experienced conflict with some of my colleagues." Participant P11 stated that: "There have been conflicts experienced concerning not coming to class on time. We earn money by (teaching). Some of our colleagues go to classroom very late and he/she revokes students learning right. I do not approve of staying silent in this situation and I say what is needed."

Some participant stating that the duty of watching is extremely important for the safety of the school expressed that some teachers do not obey the rules of duty of watch. In this regard, participant P7 said: "I was watching outside in break time. I saw that a teacher fell and get injured seriously. I waited for the teacher who is responsible for watching to come for a while nobody arrived. I had to help. I could not remain indifferent when I saw that the teacher was having a cup of tea and I discussed with him." The participant thinks that conflicts arising from the differences of teaching a lesson, social activities and disciple of student depend on that the teachers cannot develop a common behavior policy regarding similar cases. Even, the teachers that want to show $\mathrm{him} /$ her up, use inconsistent methods for providing student discipline and does not comply with the program about teaching the lessons causes conflicts. The reasons for conflict depending on the way of doing things are presented in Figure 1.

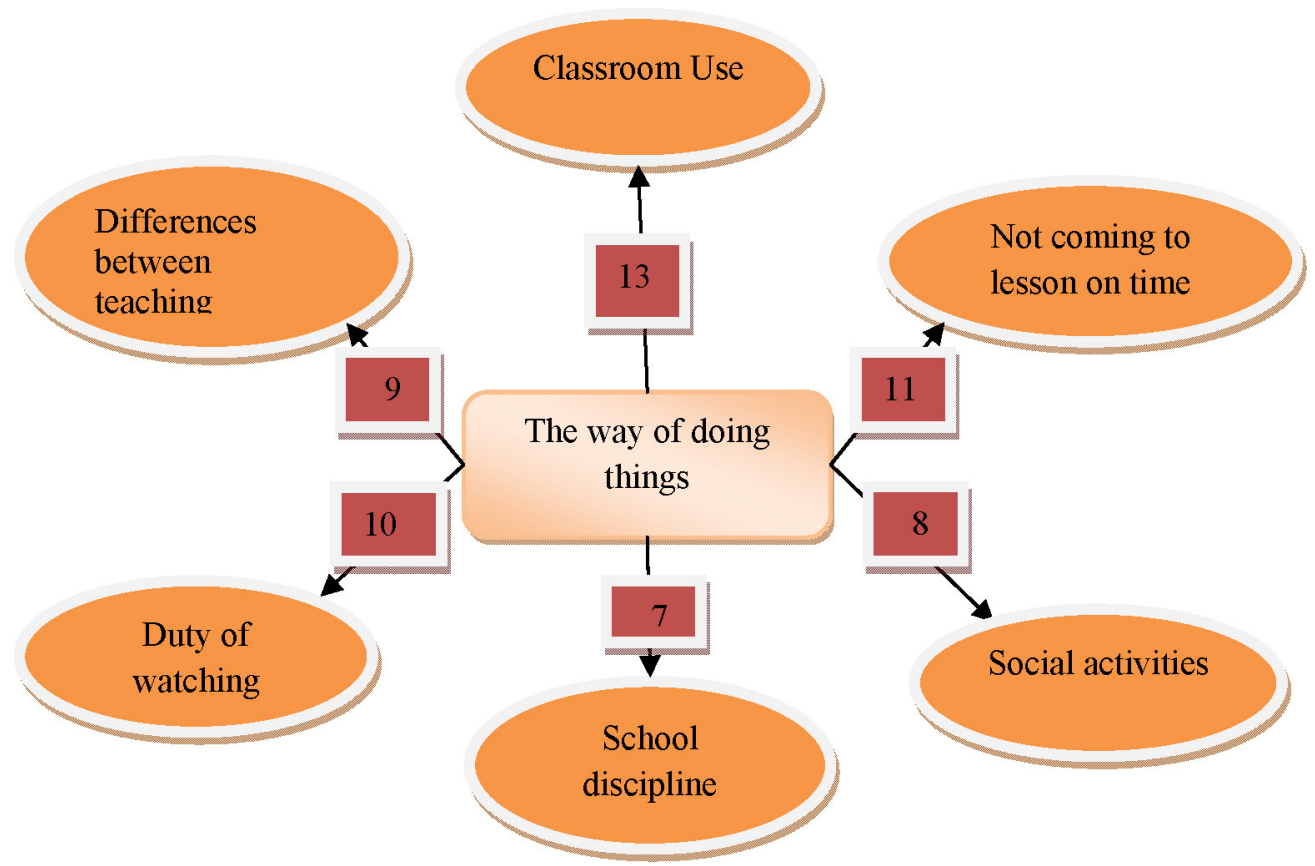

Figure 1. The reasons for conflicts stemming from the way of doing thing

\subsubsection{Teachers' Views Regarding Conflicts Stemming from Individual Differences}

According to views of participants, syndicate activities ranks first among the conflicts depending on individual differences. Political views, cultural differences, different perspectives regarding education system, personality structure, and gender succeed it respectively. Teachers stated that conflicts occur time to time between the teachers who have different syndicates and political views, they emphases that as long as this situation does not 
harm school, this conflict should be considered normal. On this subject, Participant P14 expressed that: "I cannot tolerate when I hear sentences regarding my syndicate or political view and I start discussing. While everybody is supposed to respect each other about this subject, I don't approve of this kind of bullying in the school environment. I say my piece but anyone gives up his opinions. So, we hurt each other in vain." Teachers stating that there are teachers coming from every part in the school where they work, they sometimes experience conflict depending or cultural differences. In these subject participant P6 emphases that: "Sometimes, some of my colleagues' speech, behaviors, habitude, traditions irritate me. Next thing you know that they started kidding my food culturelfood way. The fact that we do not come from the same culture does not give them right for kidding my values. Then I defend my own culture and conflict occurs unavoidably."

The participants who stated that conflicts occur often concerning the country's education system expressed that considering the reason for every conflict experienced in the schools is education system means evading responsibility. Some of the participants stated that personality structure and gender factors cause time to time conflicts. In this subject, the participant P17 said: "we come from male-dominant culture. Even if being a woman can mean that we are wrong. Therefore, we feel obliged to defend ourselves more often", while the Participant P20 underlined the personality structure and stated: "Our personality is formed according to hereditary factors and experiences. Some of us are introvert while some of us are unpermissive, some of us are fun and experiencing the conflicts in such an environment where different people are present is, of course, normal." The reasons for conflicts stemming from individual differences is presented in Figure 2.

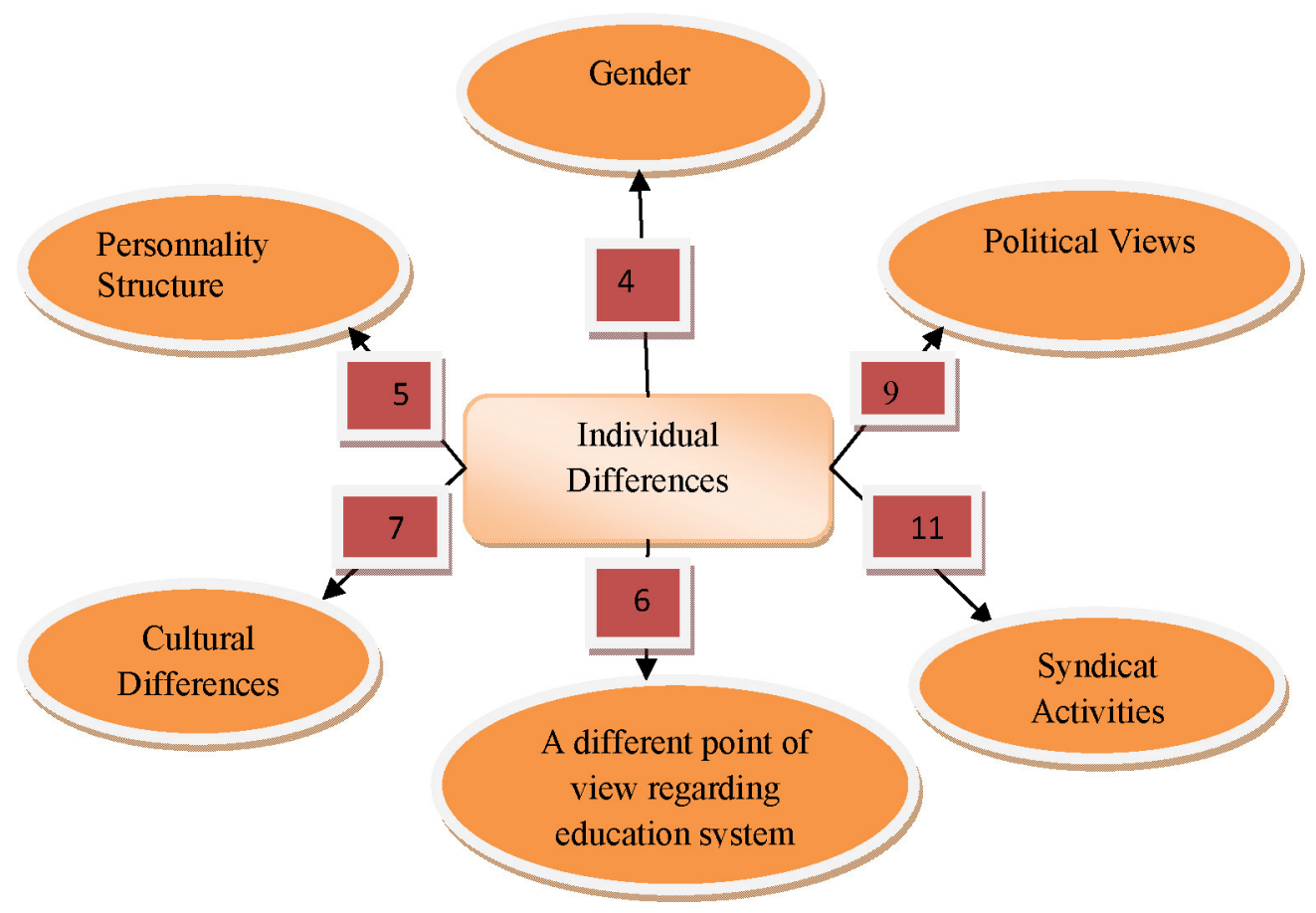

Figure 2. The reasons for conflicts stemming from individual difference

\subsubsection{Teachers' Views Regarding Conflicts Stemming from the School Management}

According to the views of the participants, communication problems rank first among the reasons for conflicts stemming from the school management. Respectively, not having executive training, lesson program, work distribution, control activities and not supporting innovations succeed this. The participants who stated that they are having communication problems with managers, they attribute this subject to that managers are incapable of communicating, they are not asking opinions of teachers for the decisions regarding school and people are gossiping too much in school. In this subject, the Participant P9 expressed that: "I find the managers unsuccessful regarding communication. For example, a duty was assigned to me regarding parents outside the school and I learned this accidentally from another teacher. I do not understand why this kind of decisions is taken without asking me. As a result, I refused the duty and, of course, I had conflict with the management." In this subject, the participant P18 said that: "Our new managers were working as teachers with us as recently as 
yesterday. It is not possible to understand this. If you select people according to their political view and syndicates to which they are a member-instead of their qualification-you assign the one who is not qualified for school management. If my manager expects respect from me, he/she is required to have more experience than me."

The participants attribute conflicts experienced concerning the lesson program and work distribution to the unfair attitudes of managers. In this subject, the participant P5 expressed that: while the duties are distributed in the meeting the easiest duties were assigned to the teachers who are close to the management. So, I do not fulfill these duties properly and I am having a conflict with the management while the Participant P2 underlined his experience similarly that: "While I teach 18 lessons and I have no free day, my colleague teach 24 hours but he/she a has free day. This and this kind of unfair implementations face off us against the managers." The participants who criticize that school management use control activities as to put pressure on them stated that bureaucratic affairs are carried out with controls and controls do not contribute to education and training. In this subject, the participant P1 stated that "I expect from my school manager to take measures so as to increase my training and education success among the control activities. However, the only question addressed to me: 'Are your documents full?' When I transmit my demands regarding this subject, unfortunately, I am labeled as a bad teacher at once." The reasons for conflict arising from school management have been shown in Figure 3.

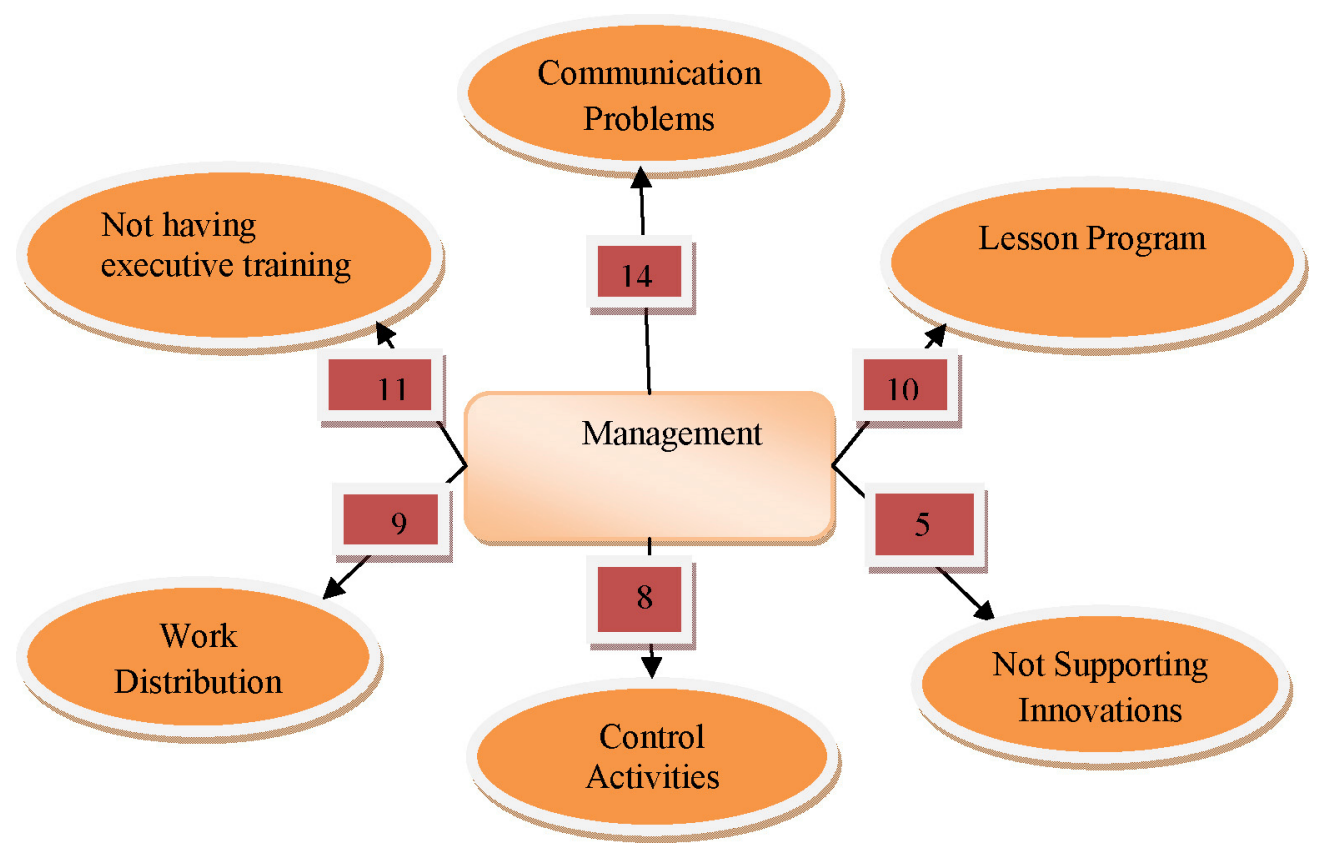

Figure 3. The reasons for conflict stemming from school management

\subsubsection{Teachers' Views Regarding School Shareholders with Whom They Experience}

The managers have the first rank first in the school shareholders with whom teachers experience conflict. Respectively, students, teachers and parents succeed. The findings concerning the subject are shown in Figure 4. 


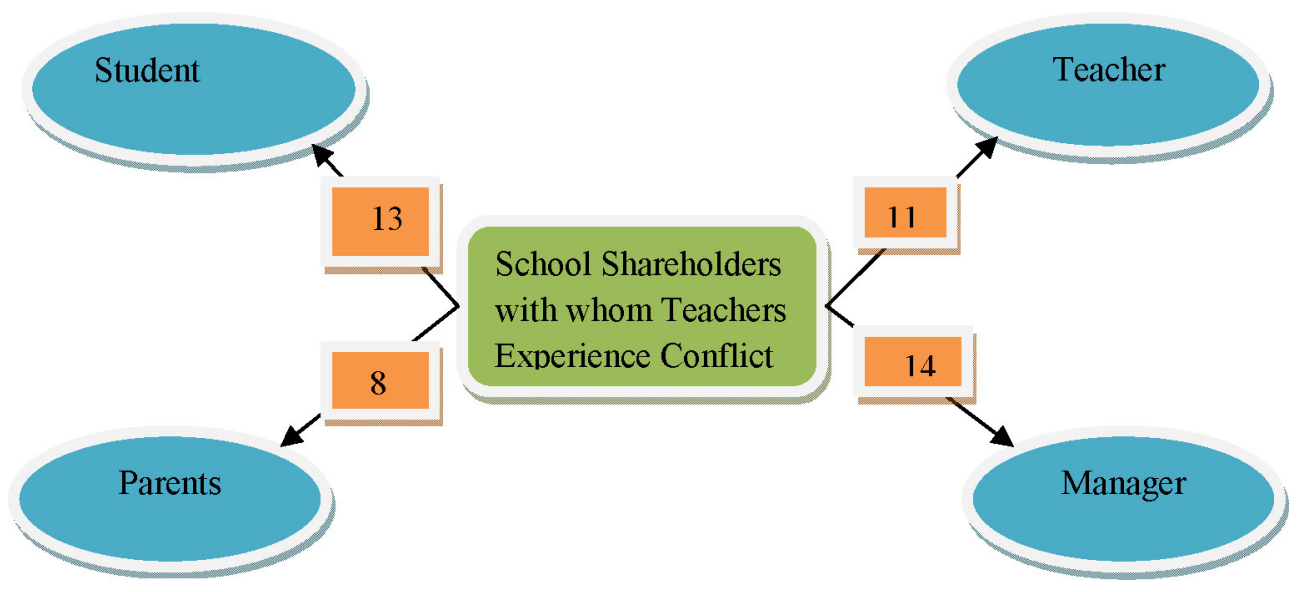

Figure 4. The shareholder of school with whom teachers experience conflict

\subsubsection{Teachers' Views Regarding Conflicts Experienced with Teachers and Managers}

For the resolution of conflicts experienced between teacher and managers, teachers use respectively avoidance, reconciliation, compromise, integration and domination. Using the strategy of avoidance mostly may be attributed to the superior-subordinate relationship between manager and teacher. While the participant P19 expressed in a manner of verifying this determination that: "When I conflict with the managers, I prefer avoiding without conflicting. Since experiencing conflict with the manager means disturbing my peace in the following days", The participant P1 stated that: "I prefer avoiding conflicting with the managers since I have difficulty in expressing myself and whatever I say, they continue as they know." The participant P8 having selected the reconciliation strategy said that: "All in all, the managers also are humans; he/she got damaged from the conflict as much as I get damaged. I am always trying to find a compromise with my managers." The participant P13 who prefers avoidance and integration strategy said: "I always consider that conflict with the managers is a waste of time. If they do not show empathy to understand, I do not want to belabor and accept to behave the way that they want". The participant P17 making explanation regarding domination underlined: "I am not afraid of conflicting with managers. If necessary, I defend my rights through legal channels but I do not resign myself to them." The distribution of the conflict strategies used by teachers in the conflicts which are experienced between teacher and manager has been presented in Figure 5.

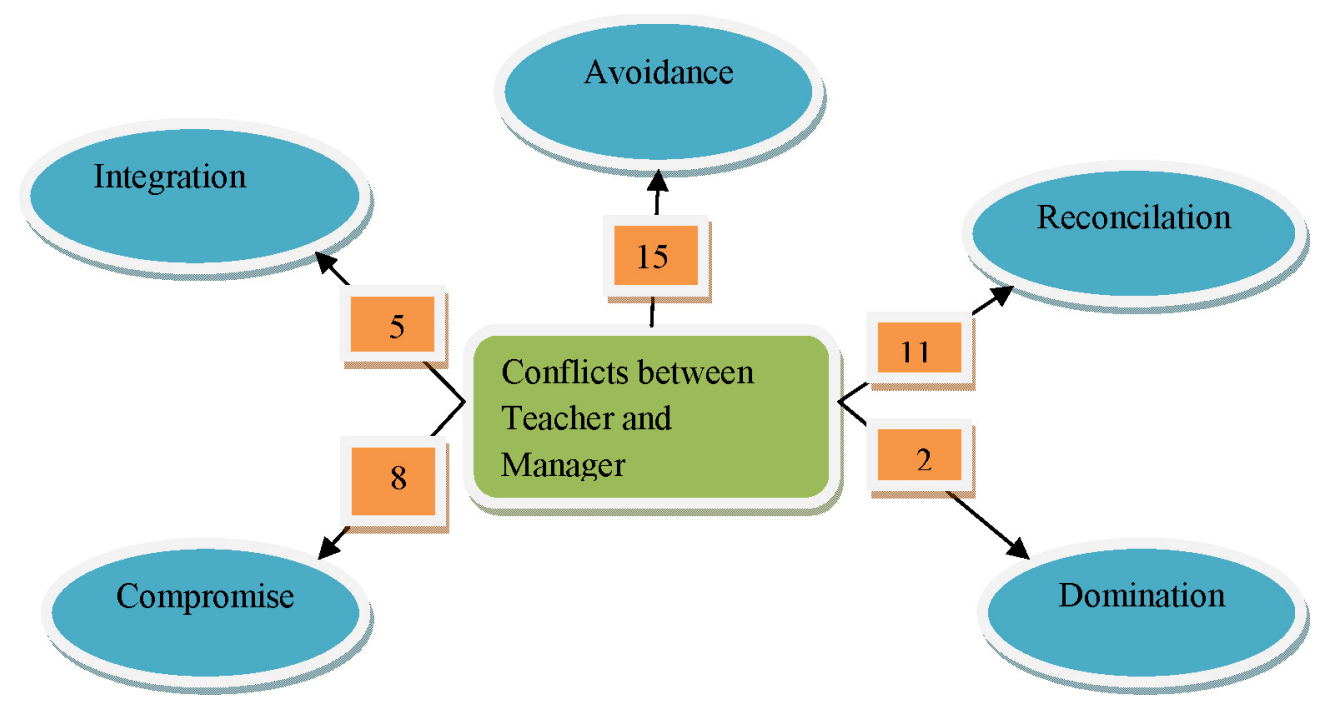

Figure 5. The distribution of the conflict strategies used by teachers in the conflicts which are experienced between teacher and manager 


\subsubsection{Teachers' Views Regarding Conflicts Experienced between Teachers and Managers}

For the resolution of conflicts experienced between teacher and teacher, teachers use respectively reconciliation, integration, domination and compromise and avoidance strategies. Using the strategy of avoidance mostly may be attributed to being in equal position. While the participant P10 expressed in a manner of supporting this that: "I can resolve the conflicts with my colleagues through reconciliation. In the end, we do not have difficulty in understanding each other since we do the same job." The participant P12 who selected the integration strategy said that: "I can act to my (friend) colleague friendly with whom I spend all day in school and I share regarding whatever the problem is and I make effort to understand her." The participant who used domination strategy stated: "Yes, he is my colleague if necessary, I struggle until he accepts my opinion." The participant P9 who finds avoidance strategy closer to herself expressed that: "It is not convenient that teachers experience conflict. This situation decreases our success. Therefore, it is necessary to avoid conflicts." The Participant P3 who selected compromise strategy expressed that: "we have to be an example for students. Therefore, I resolve conflicts that I experience through compromising so that they do not get affected negatively from the experiences." The distribution of conflict strategies used by teachers for the conflicts experienced between teacher and teacher is shown in Figure 6.
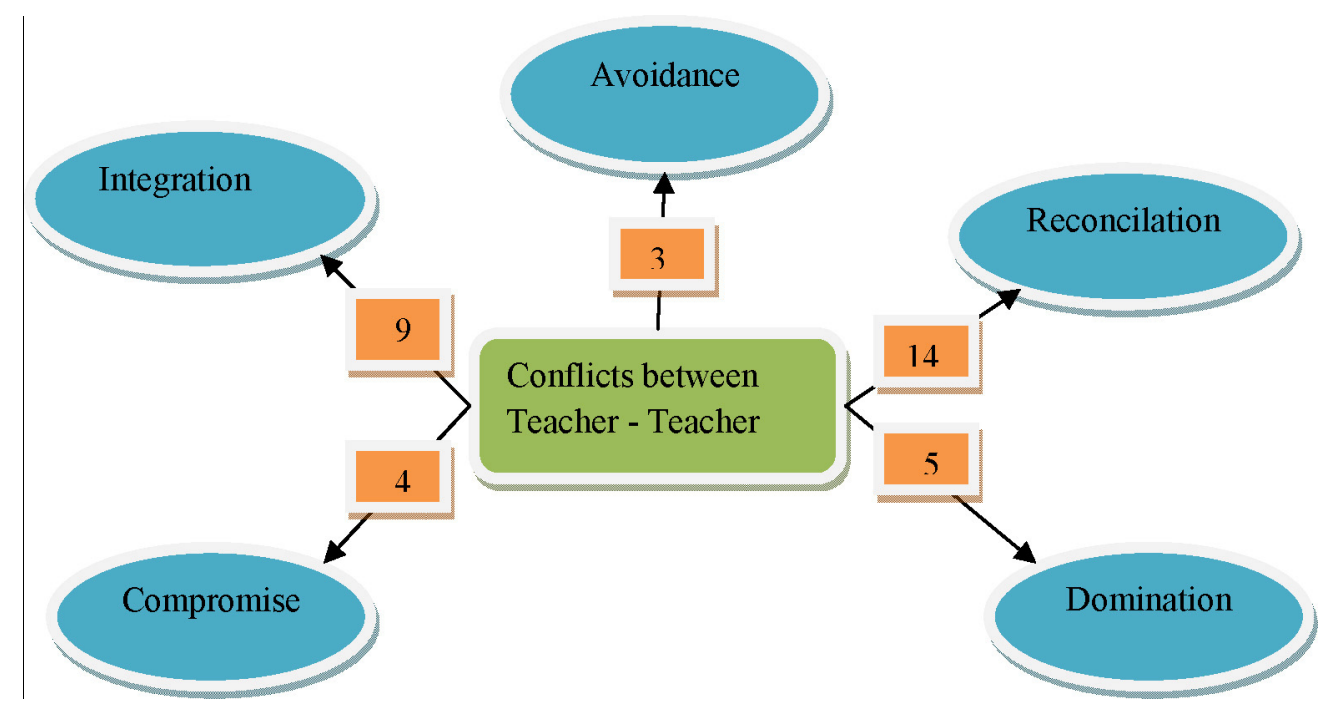

Figure 6. The distribution of conflict strategies used by teachers for the conflicts experienced between teacher and teacher

\subsubsection{Teachers' Views Regarding Conflicts Experienced between Student and Student}

For the resolution of conflicts experienced between teacher and student, teachers use respectively domination, reconciliation, integration, avoidance and compromise strategies. Preferring mostly the strategy of domination by teachers may be evaluated as clamping down on teachers. In this subject, the Participant P5 stated that: "It is very difficult to manage students of the new generation. Therefore, in order to disciple students, it is necessary that authority shows its power. It needs to implement a deterrent force." The participant P7 who dwells on reconciliation strategy said: "If you understand needs and expectations of students, it may be possible to reconcile with them. Otherwise, the relationship between teacher and student turns into a struggle." The participant P7 who made an explanation about the integration strategy stated that: "Sometimes, I put them into my children's shoes. Thus, I can find how to treat them." The participant P12 and P13 stated that experiencing conflicts harm both the teacher and the students thus, expressed similar opinions regarding that if it is necessary to avoid conflict, the strategy should be compromised. The distribution of conflict strategies used by teachers for the conflicts experienced between teacher and student is shown in Figure 7. 


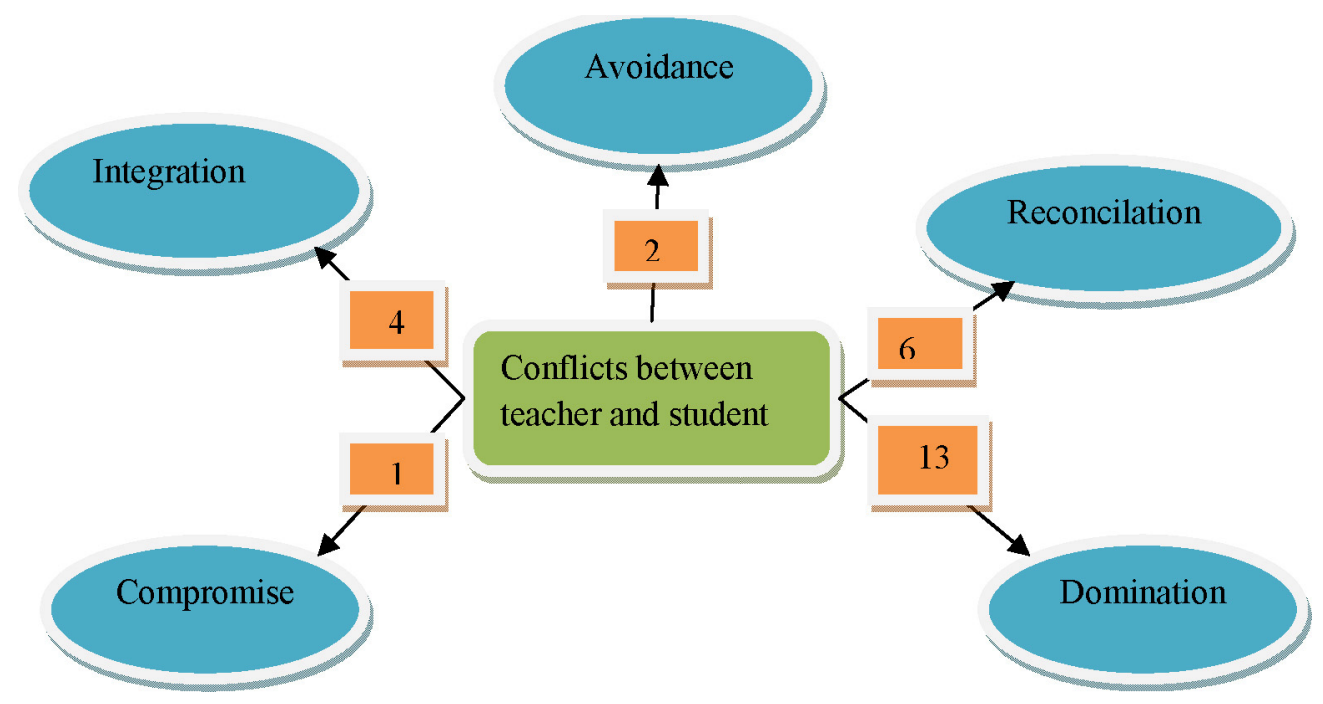

Figure 7. The distribution of conflict strategies used by teachers for the conflicts experienced between teacher and student

\subsubsection{The Views Regarding Conflicts Experienced between Teacher and Parents}

For the resolution of conflicts experienced between teacher and parents, teachers use respectively avoidance, reconciliation, compromise, dominance and integration strategies. Using the strategy of avoidance mostly may be evaluated as a result of that they abstain from parent complaints. In this subject, while the participant P7 expressed that: "I try to avoid conflicting with parents since laws and regulations stand with students and parents rather than the teacher. In the case of a slight complaint of a parent, you can be indicated that", the participant P14 who prefers reconciliation strategy explained: "Parent-teacher communication is very important for the success of the student. Thus, I think that reconciliation with parents will increase both my success and student's success." The participant K20 stated regarding integration strategy that: "as a parent also, I try to understand parents and show empathize with them." However, the Participant P14, "the relationship between teacher and parents is very important for student's success. Thus, I think that reconciliation with parents increases both student's success both my success." The participant P20 who selected compromise strategy stated that: "Parents behave bravely in terms of seeking his/her rights and they are tiring to suppress teacher. It is quite difficult to persuade them concerning their children. Therefore, I act upon their claims;" the Participant P17 stated about integration strategy: "As a parent also, I am trying to understand them and show empathy. I do my best remove the problems by taking their support." The conflict strategies used by teachers for conflicts experienced between teacher and parents have been shown in Figure 8. 


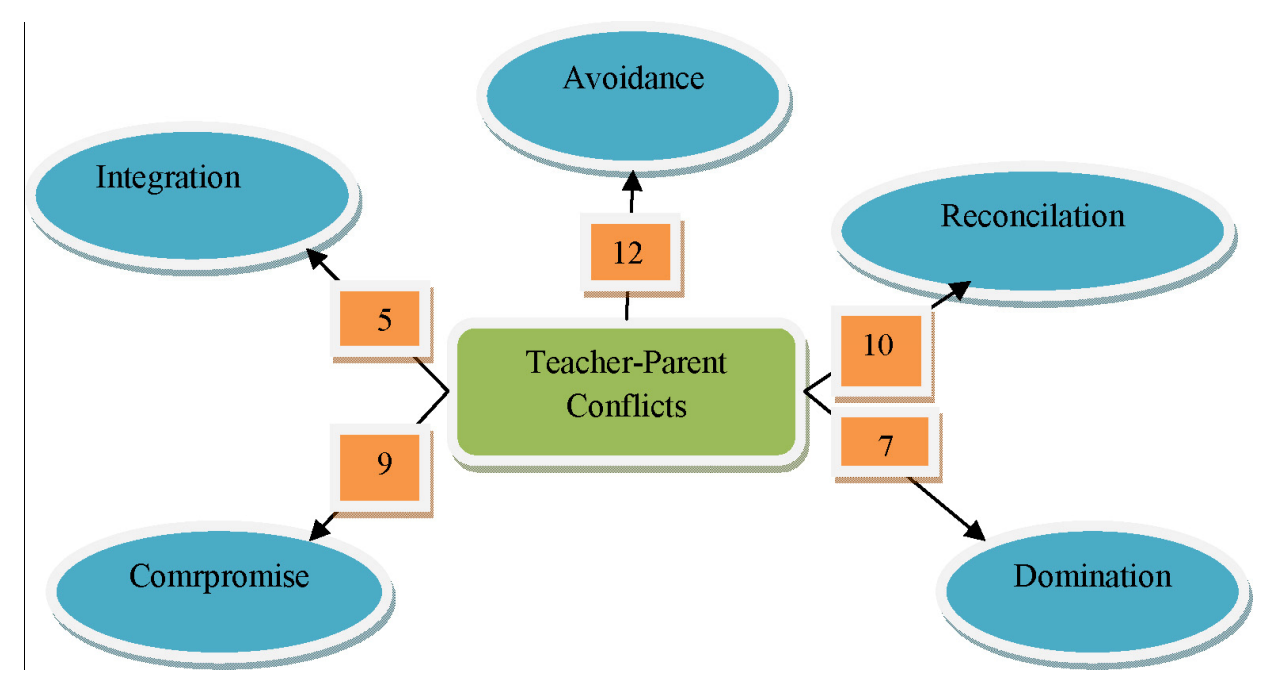

Figure 8. The distribution of conflict strategies used by teachers for conflicts experienced between teacher and parent

\section{Discussion and Conclusion}

According to the quantitative findings, the way of doing things in school ranks first among the reasons for conflicts experienced in school. Individual differences and management dimensions succeed respectively. Qualitative data has been obtained from open-ended questions for the explanation of the reasons and scale dimension of conflicts. In this context, according to the qualitative findings obtained regarding reasons for conflicts, the reason for conflicts stemming from the way of doing things are respectively use of classrooms, not coming to class on time, the duty of watching, the differences between teaching lessons, social activities and school discipline. The reasons for conflicts stemming from individual differences are found as syndicate activities, political views cultural differences, different perspectives on the education system, personality structure, and gender. Also, the reasons for conflict stemming from school management are communication problems, not getting executive training, lesson program, work distribution, control activities and not supporting innovations. According to Sarpkaya (2002), the human is in the input, process and output of educational organizations, Thus, the reasons for conflicts experienced in educational organizations vary with the human factor.

In this context, the reasons for conflict occurring in school may be expressed as different expectations and perspectives of school shareholders (Miller \& Leyden, 1999), cultural values (Özmen \& Aküzüm, 2010), personality characteristics (Yürür, 2009), having roles of ethnical origin, socio-economic status, gender (LaGour \& Tissington, 2011), teachers' different strategies preferences for resolving discipline problems (Basit, Rahman, Jumani, Chishti, \& Malik, 2010), managers' communicational and empathy skills (Arslantaş \& Özkan, 2012), providing safety in school and duties of watching (Dönmez, 2001), syndicate activities (Yaşan, 2012), different political views (Kepenekçi \& Nayır, 2014), unfair behaviors of school managers (Akgeyik, 2015), teachers' not coming to class on time (Dönmez \& Cömert, 2012), being manager without having manager training (Ada, 2000), not supporting innovations by school management (Ezgi \& Bülbül, 2012). The different study results taking place in the literature are such as to support these research results. Presentation of these results in an article forms stronger parts of this study.

When the quantitative data obtained regarding conflict strategies, it is seen that the most used strategy by teachers is reconciliation. Avoidance, integration, compromise and domination succeeds respectively this. While Güllüoğlu (2013) states in his research that teachers' conflict strategies are respectively reconciliation, dominance, integration, comprised and avoidance, Dağlı and Sığrı (2014) stated that teachers prefer mostly integration and reconciliation conflict resolution strategy. As it is seen, the studies carried out concerning teachers' conflict resolution strategies are quite limited. In the literature, conflict resolution strategies are perceived as an argument used by managers mostly. Therefore, studies conducted focus on mostly conflict management strategies used by school managers. Yıldızoğlu and Burgaz (2014) expressed that conflict management strategies against conflicts differ between in a situation and other situation. However, it is seen that school managers use mostly reconciliation and integration strategies (Özmen \& Aküzüm, 2010; Akgün, Yıldız, \& Çelik, 2009; Özmen, Aküzüm, \& Aküzüm, 2011; Kırçan \& Bostanc1, 2012; Atay, 2001; Konak \& Erdem, 
2015; Toytok \& Açıkgöz, 2013). The fact that while school managers use mostly reconciliation and integration strategies, according to this research results teachers prefers avoidance after the reconciliation and according to research results of Güllüoğlu (2013), teachers use first reconciliation and then avoidance strategy and according to research result of Güllüoğlu (2013) prefers firstly reconciliation and then domination shows that school managers and teachers have different preferred concerning their conflict resolution strategy. The reason for this difference may also be attributed to the absence of superior of school manager in school and to teachers' having both superior and subordinate. The qualitative findings of the research support this evaluation as well.

The conflict resolution strategies have been structured according to the school shareholders where teachers experience conflicts. Accordingly, the parties with which conflict experienced are respectively managers, students, teachers and parents. It is seen that teachers use mostly avoidance and reconciliation for the conflicts experienced with managers, teachers use mostly domination and reconciliation strategies for conflict experienced with students, they use mostly reconciliation and integration strategies for conflicts experienced with teachers, they use reconciliation and compensation strategies for conflicts experienced with parents. According to these results, it may show that teachers' conflict resolution strategies vary according to the position of the party with which the conflict experienced. Türnüklü (2005) expressed that student, teacher and manager views become different from each other regarding school managers' conflict resolution and tactics. In the research of Özgan (2011) reaching the result of being significant, positive and in the mid-range relation between teachers "conflict management strategies and their perception of management assessment reveals that teachers" preferences may vary.

According to the result of this research, it is seen that there is not any common resolution policy in schools. The findings of Türnüklü, Şahin and Öztürk (2002) concerning that there is not any common binding all people conflict resolution language and policy, and findings of Hakvoort and Olsson (2015) concerning teachers does not have any special knowledge, skill and any support for this subject take place in the literature. In this regard, acting as a team on conflicts (Sharma, 2014), supporting conflict resolution education and positive behaviors (Lane-Garon, Yergat, \& Kralowec, 2012; Koçak \& Başkan, 2013; Nelson, Shechter, \& Ben-Ari, 2014) and using positive (Larusso \& Selman, 2011), constructive, integrating (Trinder, Wertheimb, Freeman, Sanson, Richardsond, \& Hunt, 201) and cooperative resolution strategies (Freeman, Wertheim, \& Trinder, 2014; Jones, 2004), using drama strategy for conflict resolution (Chinyowa, 2013) will make learning environment in school more proper.

The suggestions regarding the research have been structured through "conflict management model in school" which is formed by benefiting research findings and literature. The model has been presented in Figure 9 . 


\section{CONFLICT MANAGEMENT MODEL IN SCHOOL}

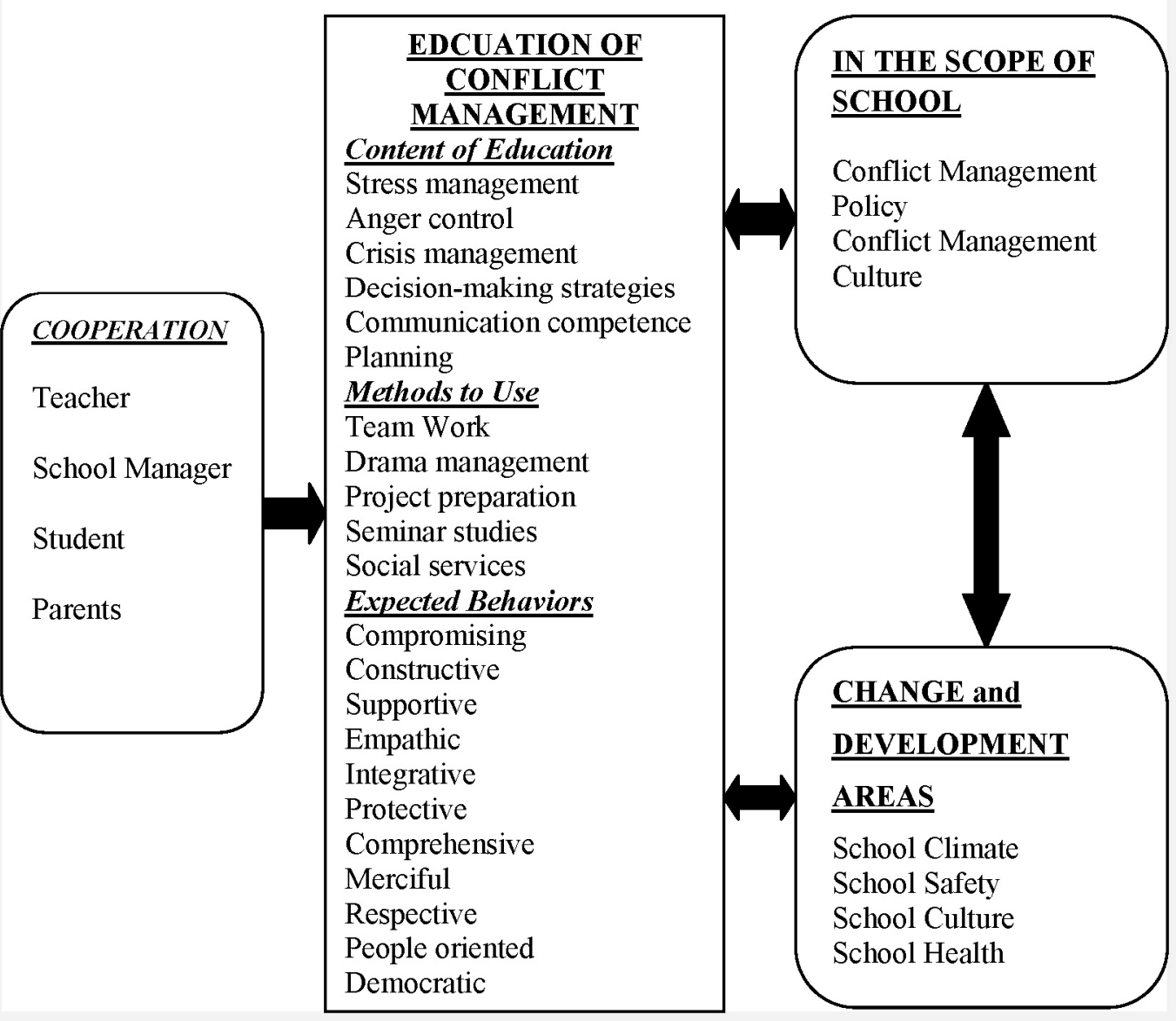

Figure 9. Conflict management model in school

Forming of conflict management from learnable behaviors forms the main idea of the model. Conflict management model first requires the cooperation of school shareholders. Conflict management education in school is set with the voluntary participation of school shareholders. The Content of the education includes stress management, anger control, crisis management, decision-making strategies, communication competence and planning. Education methods to be used include teamwork based on experience, drama management, Project preparing, seminar studies, and social services. Acquisition of these behaviors provides conflict management policy and conflict management culture in school. The behaviors that have turned to policy and culture provide development and change of school climate, school safety, school culture, school health. The school shareholders who are affected by this change and development will be able to carry out studies of higher quality regarding conflict management.

\section{References}

Açıkalın, A. (1998). Toplumsal kurumsal ve teknik yönleriyle okul yöneticiliği. Ankara: Pegem A Yayıncılık.

Akgeyik, G. (2015). Anadolu liselerinde görevli yönetici ve ögretmenlerin örgütsel adalet algıları (Diyarbakır ili örneği). Yayınlanmamış yüksek lisans tezi. Dicle Üniversitesi Eğitim Bilimleri Enstitüsü, Diyarbakır. Retrieved from http:/hdl.handle.net/11468/806

Akgün, N., Yıldız, K., \& Çelik, D. (2009). Ortaöğretim okulu yöneticilerinin öğretmenlerle aralarındaki çatışmaları yönetme yöntemleri. Abant İzzet Baysal Üniversitesi Eğitim Fakültesi Dergisi, 89-101. Retrieved from http://www.efdergi.ibu.edu.tr/index.php/efdergi/article/download/1047/1936

Altunışık, R., Coşkun, R., Bayraktaroğlu, S., \& Yıldırım, E. (2005). Sosyal bilimlerde araştırma yöntemleri. Sakarya: Sakarya Kitabevi. 
Arslantaş, H. İ., \& Özkan, M. (2012). Okul müdürlerinin çatışma çözmede yapıc1-yıkıcı olmaları ile öğretim liderliği arasındaki ilişki. Dumlupınar Üniversitesi Sosyal Bilimler Dergisi, 34, 231-240. Retrieved from http://birimler.dpu.edu.tr/app/views/panel/ckfinder/userfiles/17/files/DERG_/34/231-240.pdf

Atay, K. (2001). Okul müdürlerinin çatışmaları çözümleme stratejilerine ilişkin öğretmen okul müdürü ve denetmen algıları. Kuram ve Uygulamada Eğitim Yönetimi, 25(25), 21-35. Retrieved from http://dergipark.ulakbim.gov.tr/kuey/article/download/5000050842/5000048085

Basit, A., Rahman, F., Jumani, N. B., \& Malik, S. (2010). An analysis of conflict resolution strategies in pakistan schools. International Journal of Academic Research, 2(6), 212-218. Retrieved from http://connection.ebscohost.com/c/articles/56681646/analysis-conflict-resolution-strategiespakistani-school $\mathrm{s}$

Canlı, E. (2001). Örgütlerde kişiler arası çatışmalar. Yayınlanmamış yüksek lisans tezi, İstanbul Üniversitesi SBE, İstanbul.

Ceylan, A., Ergün, E., \& Alpkan, L. (2011). Çatışmanın sebepleri ve yönetimi. Doğuş Üniversitesi Dergisi, 1(2), 39-51. Retrieved from http://openaccess.dogus.edu.tr/bitstream/handle/11376/630/ceylan\%2020 00.pdf? sequence $=1$

Chinyowa, K. (2013). Exploring conflict-management strategies through applied drama: A Wits University case study. Matatu-Journal for African Culture and Society, 44(1), 39-53.

Cohen, R. (2005). Students resolving conflict: Peer mediation in schools. Culver City, CA: Good Year Books.

Cohen, L., Manion, L., \& Morrison, K. (2007). Observation. Research methods in education, 6, 396-412.

Conerly, K., \& Tripathi, A. (2004). What is your conflict style? Understanding and dealing with your conflict style. Journal for Quality and Participation, 27(2), 16-20. Retrieved from https://www.scribd.com/doc/20878222/Conerly-and-Tripathi-What-is-Your-Conflict-Style

Creswell, J. W. (2013). Qualitative inquiry and research design. London: Sage Publication.

Dağli, B., \& Siğri, U. (2014). The leaders role in conflict management as mediator. Research Journal of Business and Management, 1(2), 87-102. Retrieved from http://dergipark.ulakbim.gov. $\operatorname{tr} / \mathrm{rjbm} / \mathrm{article} / \mathrm{view} / 5000075382$

Demir, M. (2010). Örgütsel çatışma yönetiminde duygusal zekanın etkisi: Konaklama işletmelerinde işgörenlerin algılamaları üzerine bir çalışma. Dogus University Journal, 11(2), 199-211. Retrieved from http://journal.dogus.edu.tr/index.php/duj/article/view/19

Dönmez, B. (2001). Okul güvenliği sorunu ve okul yöneticisinin rolü. Kuram ve Uygulamada Eğitim Yönetimi, $7(1)$, 63-74. Retrieved from http://dergipark.ulakbim.gov.tr/kuey/article/download/5000050844 15000048087

Dönmez, B., \& Cömert, M. (2009). Öğretmen adaylarının kendilerinin ve uygulama öğretmenlerinin sınıf içi istenmeyen öğrenci davranışları ile baş etme konusundaki yeterliliklerine ilişkin algıları. Ahi Evran Üniversitesi Kırşehir Eğitim Fakültesi Dergisi, 10(2), 47-55. Retrieved from http://kefad.ahievran.edu.tr/archieve/pdfler/Cilt10Sayi2/JKEF_10_2_2009_47_55.pdf

Ezgi, G., \& Bülbül, T. (2012). İlköğretim okulu yöneticilerinin yenilik yönetimi yeterliklerine ilişkin öğretmen algıları. Mersin Üniversitesi Eğitim Fakültesi Dergisi, 8(2), 97-119. Retrieved from http://dergipark.ulakbim.gov.tr/mersinefd/article/view/1002000240

Fraenkel, J. R., \& Wallen, N. E. (2006). How to design and evaluate research in education. New York: McGraw-Hill.

Freeman, E., Wertheim, E. H., \& Trinder, M. (2014). Teacher perspectives on factors facilitating implementation of whole school approaches for resolving conflict. British Educational Research Journal, 40(5), 847-868. http://dx.doi.org/10.1002/berj.3116

Fritz, S., Brown, F. W., Lunde, J. P., \& Banset, E. A. (1999). Interpersonal skill for readership. NJ: Printice Hall.

Güllüoğlu, Ö. (2013). Kayseri'de hizmet veren özel ilköğretim okulu öğretmenlerinin çatışma faktörlerinin ve çatı̧̧ma yönetimi stratejilerinin analizi. İletişim Kuram ve Araştırma Dergisi, 36, 194-218. Retrieved from http://iletisimdergisi.gazi.edu.tr/site/index.php/IKAD/article/view/8 
Gümüşeli, A. İ. (1994). İzmir ortaöğretim okullarl yöneticilerinin öğretmenler ile aralarındaki çatışmaları yönetme biçimleri. Yayınlanmamış doktora tezi, Ankara Üniversitesi, Ankara. Retrieved from http://acikarsiv.ankara.edu.tr/browse/25675

Johnson, D. W., \& Johnson, R. T. (1996). Conflict resolution and peer mediation programs in elementary and secondary schools: A review of the research. Review of Educational Research, 66(4), 459-506. http://dx.doi.org/10.3102/00346543066004459

Jones, T. S. (2004). Conflict resolution education: The field, the findings, and the future. Conflict Resolution Quarterly, 22(1/2), 233-267. http://dx.doi.org/10.1002/crq.100

Hakvoort, I., \& Olsson, E. (2014). The School's democratic mission and conflict resolution: Voices of swedish educators. Curriculum inquiry, 44(4), 531-552. http://dx.doi.org/10.1111/curi.12059

Iordanides, G., \& Mitsara, S. (2014). Consequences of conflict in the functioning of primary schools in Greece. Jurnal internasional ISEA, 42(2), 127-141. Retrieved from http://connection. ebscohost.com/c/articles/97394715/consequences-conflict-functioning-primary-schools-greece

İnand1, Y., Tunç, B., \& Gündüz, B. (2013). Okul yöneticilerinin özyeterlik algıları ile çatışmayı çözme stratejileri arasındaki ilişki. Kuram ve Uygulamada Eğitim Yönetimi, 2(2), 275-294. Retrieved from http://dergipark.ulakbim.gov.tr/kuey/article/view/5000050478

Karip, E. (2003). Çatı̧ma yönetimi. Ankara: Pegem A Yayıncılık.

Karakuş, M., \& Çankaya, İ. H. (2009). Okul yöneticilerinin kişilik özelliklerinin çatışma çözme stratejileri üzerindeki etkisi. Adıyaman Üniversitesi Sosyal Bilimler Enstitüsü Dergisi, 3, 111-118. Retrieved from http://dergipark.ulakbim.gov.tr/adyusbd/article/view/5000041824

Karasar, N. (2011). Bilimsel Araştırma Yöntemleri. Ankara: Nobel Yayıncılık.

Kepenekci, Y. K., \& Nayır, K. F. (2014). Okul iklimini insan haklarına duyarll1ık boyutunda sorgulama: Liseler üzerine bir araştırma. Trakya Üniversitesi Eğitim Fakültesi Dergisi, 4(1), 1-16. Retrieved from http://dergipark.ulakbim.gov.tr/trkefd/article/view/5000081050

Kırçan, E., \& Bostancı, A. B. (2012). Conflict management strategies that administrators at primary schools use at managing conflict. Sakarya Üniversitesi Eğitim Fakültesi Dergisi, 24(24), 45-62. Retrieved from http://dergipark.ulakbim.gov.tr/sakaefd/article/view/5000003860

Koçak, S., \& Baskan, G. A. (2013). Okul müdürleri tarafından kullanılan çatışma yönetim yöntemlerinin etkililik düzeyleri. Hacettepe Üniversitesi Eğitim Fakültesi Dergisi, 44(44), 212-214. Retrieved from http://www.efdergi.hacettepe.edu.tr/yonetim/icerik/makaleler/263-published.pdf

Konak, M., \& Erdem, M. (2015). Öğretmenlerin görüşlerine göre ilkokul yöneticilerinin etik liderlik davranışları ile çatışma yönetme stratejileri arasındaki ilişki. Kuram ve Uygulamada Eğitim Yönetimi, 21(1), 69-91. http://dx.doi.org/10.14527/kuey.2015.004

LaCour, M. M., \& Tissington, L. D. (2011). Conflict Resolution in the multicultural classroom. Journal of Instructional Psychology, 38(1), 8-17. Retrieved from http://eric.ed.gov/?id=EJ952145

Lane-Garon, P., Yergat, J., \& Kralowec, C. (2012). Conflict resolution education and positive behavioral support: A climate of safety for all learners. Conflict Resolution Quarterly, 30(2), 197-217. http://dx.doi.org/10.1002/crq.21059

LaRusso, M., \& Selman, R. (2011). Early adolescent health risk behaviors, conflict resolution strategies, and school climate. Journal of Applied Developmental Psychology, 32(6), 354-362. http://dx.doi.org/10.1016/j.appdev.2011.05.003

Laursen, B., \& Hafen, C. A. (2010). Future directions in the study of close relationships: Conflict is bad (except when it's not). Social Development, 19(4), 858-872. http://dx.doi.org/10.1111/j.1467-9507.2009.00546.x

Lipsky, D. B., Seeber, R., \& Fincher, R. D. (2003). Emerging systems for managing workplace conflict. San Francisco: Iossey-Bass.

Mayer, R. J. (1990). Conflict management. the courge to confront. Columbus Richland: Battelse Press.

Miller, A., \& Leyden, G. (1999). A coherent framework for the application of psychology in schools. British Educational Research Journal, 25, 389-400. http://dx.doi.org/10.1080/0141192990250308 
Miles, M. B., \& Huberman, A. M. (1994). Qualitative data analysis (2nd ed.). Thousand Oaks, CA: Sage Publications.

Nelson, N., Shechter, D., \& Ben-Ari, R. (2014). Procedural justice and conflict management at school. Negotiation Journal, 30(4), 393-419. http://dx.doi.org/10.1111/nejo.12074

Nural, E., Ada, Ş., \& Çolak, A. (2012). Öğretmen algılarına göre okul müdürlerinin kullandıkları çatışma yönetimi yöntemleri. Atatürk Üniversitesi Sosyal Bilimler Enstitüsü Dergisi, 16(3), 197-210. Retrieved from http://e-dergi.atauni.edu.tr/ataunisosbil/article/view/1020009156

O’toole, J. (1999). Leadership A to Z: A guide for the appropriately ambitious. San Francisco: Jossey-Bass Publishers.

Özgan, H. (2011). Örgütsel davranış bağlamında öğretmenlerin örgütsel adalet, güven, bağl1l1k, yönetici değerlendirme ve çatışma yönetimi stratejileri algıları arasındaki ilişkilerin incelenmesi. Kuram ve Uygulamada Ĕ̈itim Bilimleri, 1(11), 247-229. Retrieved from https://www.edam.com.tr/kuyeb/pdf/tr/8972b30a03b05784c07ef2586b64ac7fanTAM.pdf

Özmen, F., \& Aküzüm, C. (2010). Okulların kültürel yapısı içinde çatışmalara bakış açısı ve çatışma çözümünde okul yöneticilerinin liderlik davranışları. Sosyal ve Beşeri Bilimler Dergisi, 2(2), 65-75. Retrieved from http://dergipark.ulakbim.gov.tr/sobiadsbd/article/view/5000136829

Özmen, F., Aküzüm, C., \& Aküzüm, L. (2011). Yönetici görüşlerine göre, okul mensuplarının okullardaki çatışma sonuçlarına yönelik tavır alışları. Dicle University Journal of Ziya Gokalp Education Faculty, 16, 86-100. Retrieved from http://www.zgefdergi.com/DergiPdfDetay.aspx?ID=185

Öztaş, U., \& Akın, O. (2009). Örgütsel çatışma yönetiminde cinsiyet farklılıkları: Antalya serbest bölgesinde bir araştırma. Organizasyon ve Yönetim Bilimleri Dergisi, 1(1), 9-24. Retrieved from http://dergipark.ulakbim.gov.tr/oybd/article/download/5000145135/5000132475

Parker, C., \& Stone, B. (2003). Developing management skills for leadership. London: Prentice Hall.

Prause, D., \& Mujtaba, B. G. (2015). Conflict management practices for diverse workplaces. Journal of Business $\begin{array}{lllll}\text { Studies } & \text { Quarterly, } & \text { 6(3), } & \text { Retrieved } & \text { from }\end{array}$ http://jbsq.org/wp-content/uploads/2015/03/March_2015_2.pdf

Rahim, M. A. (1983). Rahim Organizational Conflict Inventory. Consulting Psychologists Press. http://westallen.typepad.com/files/rahim-organizational-conflict-inventory.pdf

Ruble, T. L., \& Thomas, K. W. (1976). Support for a two-dimensional model of conflict behavior. Organizational Behavior and Human Performance, 16(1), 143-155. http://dx.doi.org/10.1016/0030-5073(76)90010-6

Quinn, R., Faerman, S., Thompson, M., \& McGrath, M. (2003). Becoming a Master Manager: A Competency Approach. Hoboken, NJ: John Wiley \& Sons, Inc.

Sarpkaya, R. (2002). Eğitim örgütlerinde çatışma yönetimi ve bir örnek olay. Kuram ve Uygulamada Eğitim Yönetimi, 8(3), 414-429. Retrieved from http://dergipark.ulakbim.gov.tr/kuey/article /viewFile/5000050798/5000048044

Sayles, L. R. (1993). The working leader. The triumph of high performance over conventional management principles. New York: The Free Press.

Serin, A. E., Balkan, M. O., \& Soran, S. (2014). Çatışma yönetim stratejilerinin izlenim yönetimi taktiklerine etkisi: Universite öğrencileri üzerine bir araştırma. Elektronik Sosyal Bilimler Dergisi, 50(50), 23-37. http://dx.doi.org/10.17755/esosder.38968

Seval, H. (2006). Çatışmanın etkileri ve yönetimi. Manas Sosyal Bilimler Dergisi, 15, 245-254. Retrieved from http://journals.manas.edu.kg/mjsr/oldarchives/Vol08_Issue15_2006/474.pdf

Steed, D. (1985). Disruptive pupils, disruptive schools: Which is the chicken? Which is the egg? Educational Research, 27(1), 3-8. http://dx.doi.org/10.1080/0013188850270101

Shabbir, N., Atta, M., \& Adil, A. (2014). Conflict management and decision making styles in college management. Journal of Behavioural Sciences, 24(2), 52-68. Retrieved from http://pu.edu.pk/images/journal/doap/PDF-FILES/Abstract\%20No.\%204_v24_no2_14.pdf 
Sharma, P. (2014). Ways of conflict resolution adopted by supporting and non-teaching staff in management schools. Pranjana: The Journal of Management Awareness, 17(2), 46-55. http://dx.doi.org/10.5958/0974-0945.2014.00004.1

Stepsis, J. A. (2003). Pfeiffer's classic activities for managing conflict at work. In J. Gordon (Ed.), Conflict-Resolution Strategies (pp. 19-23). Jossey-Bass/Pfeiffer: A Wiley İmprint.

Stulberg, J. B. (1987). Taking charge/managing conflict. Lexington, MA: Lexington Books.

Tavşancıl, E., \& Aslan, E. (2001). Sözel, yazılı ve diğer materyaller için içerik analizi ve uygulama örnekleri. İstanbul: Epsilon.

Tjosvold, D. (1991). The conflict-positive organiation. Stimulate diversity and create unity. New York: Addison-Wesley publishing Company.

Tjosvold, D. (1997). Conflict within interdependence: Its value for productivity and individuality. Using conflict in organizations, 23-37. http://dx.doi.org/10.4135/9781446217016

Toytok, E. H., \& Açıkgöz, A. (2013). Öğretmen görüşlerine göre okul yöneticilerinin çatışma yönetim stilleri ile örgütsel adalet algıları arasındaki ilişki. Anatolian Journal of Educational Leadership and Instruction, 1(2), 24-36. Retrieved from http://dergipark.ulakbim.gov.tr/ajeli /article/download/1064000017/1064000017

Trinder, M., Wertheim, E. H., Freeman, E., Sanson, A., Richardson, S., \& Hunt, S. (2010). Comparison of the effectiveness of two forms of the enhancing relationships in school communities project for promoting cooperative conflict resolution education in Australian primary schools. Journal of Peace Education, 7(1), 85-105. http://dx.doi.org/10.1080/17400201003640228

Türnüklü, A. (2005). Lise yöneticilerinin çatışma çözüm strateji ve taktiklerinin sosyal oluşturmacılık kuramı perspektifinden. Kuram ve Uygulamada Eğitim Yönetimi, 11(2), 255-278. Retrieved from https://pegem.net/dosyalar/dokuman/669-2011060611147-6-turnuklu.pdf

Türnüklü, A., Şahin, İ., \& Öztürk, N. (2002). İlköğretim okullarında, öğrenci, öğretmen, okul yöneticisi ve velilerin çatı̧̧ma çözüm stratejileri. Kuram ve Uygulamada Eğitim Yönetimi, 32(32), 574-594. Retrieved from https://www.pegem.net/dosyalar/dokuman/758-2011070610231-turnuklu.pdf

Uysal, İ. (2004). Örgütsel çatışma yönetimi ve Türkiye Cumhuriyet Merkez Bankası'na yönelik bir uygulama. Türkiye Cumhuriyet Merkez Bankası, Uzmanlık Yeterlilik Tezi. Retrieved from http://www3.tcmb.gov.tr/kutuphane/TURKCE/tezler/isauysal.pdf

Vasilescu, L., Popescu, C., \& Popescu, D. (2012). The management of educational conflict-a continuous process. Managerial Challenges of the Contemporary Society, 4, 236-238. Retrieved from $\mathrm{http} / / / \mathrm{www} . c e e o l . c o m /$ aspx/getdocument.aspx? $\operatorname{logid}=5 \& \mathrm{id}=252 \mathrm{dea} 7 \mathrm{eeb} 414682 \mathrm{aa} 768663 \mathrm{f} 7950 \mathrm{da} 7$

Voronin, G. L. (1995). Conflicts in School. Russian Social Science Review, 36(3), 69-77. http://dx.doi.org/10.2753/RSS1061-1428360369

Walton, R. E. (1987). Managing conflict. interpersonel dialouge and third-party roles. California: Addison-Wesley Publishing Company.

Yasan, T. (2012). İlköğretim okulu yöneticilerinin ve öğretmenlerinin sendikalara ilişkin görüşlerinin farklı değişkenlere göre incelenmesi: Malatya il merkezi örneği. Ondokuz Mayıs Üniversitesi Eğitim Fakültesi Dergisi, 31(1), 271-293. Retrieved from http://dergipark.ulakbim. gov.tr/omuefd/article/view/5000035690

Yazıcıoğlu, Ġ., \& Sökmen, A. (2005). Thomas modeli kapsamında yöneticilerin çatışma yönetimi stilleri ve tekstil işletmelerinde bir alan araştırması. Ticaret ve Turizm Eğitim Fakültesi Dergisi, 1, 1-19. Retrieved from http://gazi.edu.tr/posts/download?id=136198

Yıldırım, A., \& Şimşek, H. (2011). Sosyal bilimlerde nitel araştırma yöntemleri. Ankara: Seçkin Yayıncılık.

Yıldızoğlu, H., \& Burgaz, B. (2014). Okul yöneticilerinin beş faktör kişilik özellikleriyle çatışma yönetimi stili tercihleri arasındaki ilişki. Hacettepe Üniversitesi Eğitim Fakültesi Dergisi, 29(29-2). Retrieved from http://dergipark.ulakbim.gov.tr/hunefd/article/viewFile/5000048037/5000045357

Yürür, S. (2009). Yöneticilerin çatışma yönetim tarzları ve kişilik özellikleri arasındaki ilişkinin analizine yönelik bir araştırma. CÜ İktisadi ve İdari Bilimler Dergisi, 10(1), 23-42. Retrieved from http://iibfdergi.cumhuriyet.edu.tr/archive/yneticilerinatmaynetimtarzlarvekiilikzellikleriarasndakilikininanal izineynelikbiraratrma.pdf 
Zia, Y. A., \& Syed, P. H. (2013). An exploratory study into the causes of conflict and the effect of conflict management style on outcome in a competitive workplace. Journal of Managerial Sciences, 7(2), 300-315. Retrieved from http:/www.qurtuba.edu.pk/jms/defaultfiles/JMS/72/JMSJuly December2013299-315.pdf

\section{Copyrights}

Copyright for this article is retained by the author(s), with first publication rights granted to the journal.

This is an open-access article distributed under the terms and conditions of the Creative Commons Attribution license (http://creativecommons.org/licenses/by/3.0/). 